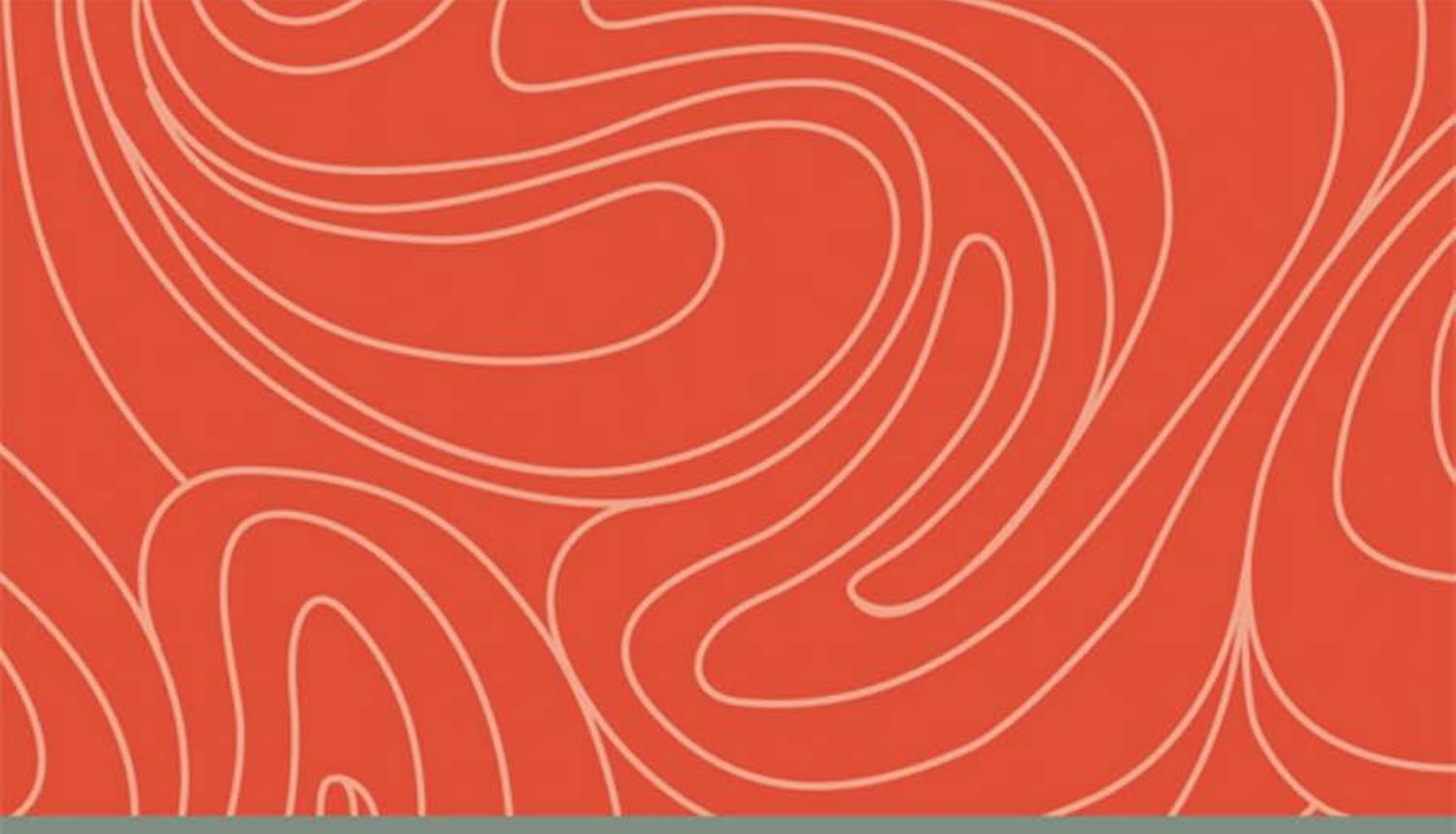

\title{
ANAÏS NIN
}

\section{A MYTH OF HER OWN}

Clara Oropeza

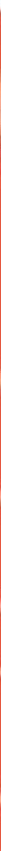


As a new-generation Nin scholar, Clara Oropeza expands Nin's mythic territory into a feminist realm of self-realization beyond the strictures of literal male autobiography and logocentric Modernism. Informed by the academic field of self-life writing, Oropeza provocatively reexamines the diary as an exploratory genre in which Nin "slants" fact into fiction largely through her creative role as a literary trickster. This is a daring, fresh interpretation of Anaïs Nin's artistic orientation.

- Suzanne Nalbantian, $\mathrm{PhD}$; author of Memory in Literature:

From Rousseau to Neuroscience (2003) and editor of Anaïs Nin: Literary Perspectives (1997)

Anaïs Nin: A Myth of Her Own is more than a groundbreaking study of a major modernist author, for this book reveals a mythic method to rival that of T. S. Eliot on Joyce, one superbly crafted by Nin to re-make being as feminine, creative, flexibly narrative, embodied and trickster-like. Oropeza traces a new direction in Modernist studies that is Jungian, feminist, ecocritical and liberatory. This superb book is a must for all serious students of Modernism, women writers, life writing, feminist theory and psychoanalytical approaches to literature, as well as scholars of interdisciplinary breakthroughs to a new paradigm in the humanities.

- Susan Rowland, PhD, author of Jung as a Writer (2005),

The Ecocritical Psyche (2012) and Remembering Dionysus (2017) 
$\because$ Taylor \& Francis

http://taylorandfrancis.com 


\section{Anaïs Nin}

Anaïs Nin: A Myth of Her Own traces Nin's literary craft by following the intimacy of self-exploration and poetic expression attained in the details of the quotidian, transfigured into fiction. By digging into the mythic tropes that permeate both her literary diaries and fiction, this book demonstrates that Nin constructed a mythic method of her own, revealing the extensive possibilities of an opulent feminine psyche.

Clara Oropeza demonstrates that the literary diary, for Nin, is a genre that with its traces of trickster archetype, among others - reveals a mercurial, yet particular understanding of an embodied and at times mystical experience of a writer. The cogent analysis of Nin's fiction alongside the posthumously published unexpurgated diaries, within the backdrop of emerging psychological theories, further illuminates Nin's contributions as an experimental and important modernist writer whose daring and poetic voice has not been fully appreciated. By extending research on diary writing and anchoring Nin's literary style within modernist traditions, this book contributes to the redefinition of what literary modernism was comprised, who participated and how it was defined.

Anaïs Nin: A Myth of Her Own is unique in its interdisciplinary expansion of literature, literary theory, mythological studies and depth psychology. By considering the ecocritical aspects of Nin's writing, this book forges a new paradigm for not only Nin's work, but for critical discussions of self-life writing as a valid epistemological and aesthetic form. This impressive work will be of great interest to academics and students of Jungian and post-Jungian studies, literary studies, cultural studies, mythological studies and women's studies.

Clara Oropeza is Professor of English Composition and Literature at Santa Barbara City College, California, U.S. Her research brings comparative mythology to literary studies and cultural theory. She is the author of several essays, most recently The (Mal)Creation of Food the Monsanto Way: Returning a Mythic Sensitivity to Food Production. She received her BA and MA in English Literature from California State University, Los Angeles and her PhD in Comparative Mythology and Literature from Pacifica Graduate Institute. 
$\because$ Taylor \& Francis

http://taylorandfrancis.com 


\title{
Anaïs Nin
}

A Myth of Her Own

Clara Oropeza

\author{
Routledge \\ 尊 Taylor \& Francis Group \\ LONDON AND NEW YORK
}


First published 2019

by Routledge

2 Park Square, Milton Park, Abingdon, Oxon OXI4 4RN

and by Routledge

7II Third Avenue, New York, NY 10017

Routledge is an imprint of the Taylor \& Francis Group, an informa business

\section{(C) 2019 Clara Oropeza}

The right of Clara Oropeza to be identified as author of this work has been asserted by her in accordance with sections 77 and 78 of the Copyright, Designs and Patents Act 1988.

All rights reserved. No part of this book may be reprinted or reproduced or utilised in any form or by any electronic, mechanical, or other means, now known or hereafter invented, including photocopying and recording, or in any information storage or retrieval system, without permission in writing from the publishers.

Trademark notice: Product or corporate names may be trademarks or registered trademarks, and are used only for identification and explanation without intent to infringe.

British Library Cataloguing-in-Publication Data

A catalogue record for this book is available from the British

Library

Library of Congress Cataloging-in-Publication Data

A catalog record for this book has been requested

Names: Oropeza, Clara, 1970- author.

Title: Anaèis Nin : a myth of her own / Clara Oropeza.

Description: Abingdon, Oxon ; New York : Routledge, $2019 . \mid$ Includes bibliographical references and index.

Identifiers: LCCN 20I80I9876 (print) | LCCN 20180I9910

(ebook) | ISBN 978I3I5I64885 (Master) | ISBN 978I35I675482

(Web PDF) | ISBN 978I35I675475 (ePub) | ISBN

978|35|675468 (Mobipocket/Kindle) | ISBN 978II 38057395

(hardback : alk. paper)

Subjects: LCSH: Nin, Anaèis, 1903-1977-Criticism and interpretation.

Classification: LCC PS3527.1865 (ebook) | LCC PS3527.1865 Z83

2019 (print) | DDC 818/.5209-dc23

LC record available at https://lccn.loc.gov/20I8019876

ISBN: 978-I-138-05739-5 (hbk)

ISBN: 978-I-3I5-I6488-5 (ebk)

Typeset in Times New Roman

by Apex CoVantage, LLC 


\section{Dedicación/Dedication}

\section{Para Mi Familia}

And for the spirit of Anaïs Nin. May her words continue inspiring those setting out on the path that she so passionately paved. 
$\because$ Taylor \& Francis

http://taylorandfrancis.com 


\section{Contents}

With gratitude $\quad \mathrm{x}$

Permissions and acknowledgments xi

Preface: tracing the faces of life, creativity and literature xii

1 Anaïs Nin: self-life writing, myth and literature 1

2 Anaïs Nin's expurgated diaries Volume One (1931-1934) and Two (1934-1939): modernism and mythopoesis

3 Risks and tricks in the myth of the diarist

4 (Un)veiling incest: the early diary of Anaïs Nin, Volume Four and Incest: From a Journal of Love

5 The literary credo of a diarist and novelist as traced in Incest: From a Journal of Love and Winter of Artifice

6 Myth, monsters and art: the labyrinths of Nin's Seduction of the Minotaur

Epilogue: tending self and nature: eco-minded writing and communitas 


\section{With gratitude}

I want to acknowledge Mark, my husband and co-conspirator in life, for always being my first reader and peerless editor. Thank you for always believing in me. I also thank you for assuring celebrations at the completion of each milestone at every stage in this process.

Thank you, Suzanne Nalbantian, for your attention to this manuscript and for your encouragement to publish this work. Your personal relationship with Nin contributed invaluable direction to my work. I thank Susan Rowland for being a supportive mentor and friend, and for always inspiring my own thinking; your support has been vital to this book.

While the writing of this book has been an act of dedication and passion for Nin's work, it has often seemed long, arduous and at times lonely. Hence, for their steady support throughout the writing of this book, my deep appreciation goes to my sisters and friends, mi pistoleras: Thelma Ruiz, Elvia Rodriguez, Hilda Shraddha Oropeza, Cris Oropeza, Luna Ruiz, Mercedes Taha, Chella Courington, April Heaslip, Carrie Hutchinson, Mona Ramirez and Nora Strejilevich. Thank you for your love and perpetual words of encouragement and for always nurturing me.

I also thank my students, whose appreciation and excitement for Nin's work continues to transform and energize me.

Finally, I want to recognize Emma Zunz for her canine support throughout this project. She has grounded my love for the non-human. I thank her for unconditional camaraderie and excuses to go for daily beach walks. 


\section{Permissions and acknowledgments}

The epigraph featured in the Preface is taken from Borderlands/La Frontera: The New Mestiza. Copyright (C) 1987, 1999, 2007, 2012. Reprinted by permission of Aunt Lute Books. I thank you Joan Pinkvoss for permission to use this passage.

The passages I use as epigraphs in Chapters 1 and 2, were taken from The Diary of Anaïs Nin, Volume One (1931-1934), The Diary of Anais Nin, Volume Two (1934-1939) and Incest: From a Journal of Love. I thank Houghton Mifflin Harcourt Publishing Company for permission to use these passages.

Thank you to Harvard press for the permission to use Emily Dickinson's poem as an epigraph in Chapter 3. This poem is located in: The Poems of Emily Dickinson, edited by Thomas H. Johnson, Cambridge, Mass.: The Belknap Press of Harvard University Press, Copyright (C) 1951, 1955 by the President and Fellows of Harvard College. Copyright (C) renewed 1979, 1983 by the President and Fellows of Harvard College. Copyright (C) 1914, 1918, 1919, 1924, 1929, 1930, 1932 , 1935, 1937, 1942, by Martha Dickinson Bianchi. Copyright (C) 1952, 1957, 1958, 1963, 1965, by Mary L. Hampson.

The original diary titles listed in Chapter 4 are taken from Anaïs Nin's archives housed in UCLA's Special Collections. I thank the Anaïs Nin Trust for giving me permission to use these original journal titles.

I thank Joan Didion and Chad Luibl, Janklow \& Nesbit Associates, for permission to use an excerpt from Joan Didion, originally published in The White Album. Copyright (C) 1979. This passage is used as an epigraph in Chapter 5.

The epigraph included in Chapter 6 is taken from "Parable of Cervantes and the Quixote," copyright (C) 1998 by Maria Kodama; translation copyright (C) 1998 by Penguin Random House LLC; from Collected Fictions: Volume 3 by Jorge Luis Borges, translated by Andrew Hurley. Used by permission of Viking Books, an imprint of Penguin Random House Publishing Group, a division of Penguin Random House LLC. All rights reserved.

An excerpt from Mina Loy's "Feminist Manifesto" is reprinted as an epigraph in Chapter 4. It is taken from The Lost Lunar Baedeker: Poems of Mina Loy. Copyright (C) 1996. Reprinted by permission of Roger Conover, literary executor of the Estate of Mina Loy.

I thank Hubert Zapf and Claire Weatherhead from Bloomsbury Publishing Plc. for permission to use an excerpt from "Literature as Cultural Ecology." Copyright (C) 2016. This is an epigraph in my Epilogue. 


\section{Preface}

\section{Tracing the faces of life, creativity and literature}

I want the freedom to carve and chisel my own face, to staunch the bleeding with ashes, to fashion my own gods out of my entrails. And if going home is denied me then I will have to stand and claim my space, making a new culture una cultura mestiza - with my own lumber, my own bricks and mortar and my own feminist architecture.

(Gloria Anzaldúa 1999)

My exploration of Anaïs Nin's (1903-1977) mythopoesis hopes to claim a space for the creative depth of a writer who ardently sought to give voice to the plurality of truths, as integral parts of her sense of self. Nin sought to fuse language with embodied experiences, including her personal visions of art, which she detailed in her diary for over 60 years. She kept a record of how language, intuition and the imagination both animates and informs the magnified, multifarious and deepened experience of the writer. It was her contention that narratives must be experienced through a triad pathway enmeshing the intellect, embodiment and imagination. This means that Nin's particular creed about the relationship between life and art is to be regarded under two distinct human needs: "one is a human need to be intimate with experience" and "then there's a second need in human nature which is to create something that has more permanence, which is the myth of our lives, the symbolic, spiritual significance of our lives" (A Woman Speaks 190).

Embracing the personal through self-investigation, as well as creating art containing the myth that holds the archetypal and spiritual, was Nin's way of critiquing the literary modes then in vogue that put emphasis on objectivity. For Nin, converging subjective experiences into art, including the profound, highly complex truths existing in multiple realms, remained an enduring interest throughout her life.

Nin ardently believed there was a way to write oneself out of the oppressive roles society imposed on a person. Women were not to reveal that they had a mind of their own, let alone uncover the multiplicity of voices and tensions in the domain of letters. For women, developing an appropriate authorial voice meant they had to cleverly overcome more than just societal disapproval; they had to defeat their own internalized socialization that posited writing was a masculine 
privilege. In subtle and not-so-subtle ways, often in terror, women risked their unguarded hearts. This means that to be a writer required the transformation of paradoxical and complex emotions. Nin reflects: "In the diary I can keep track of the two faces of reality. I have a record, I can balance one vision against another. As I write, I can dissipate the fear of alteration and loss ... [the world] is born of intuition, of feeling. The transformation required of creation terrifies me. Change, to me, represents tragedy, loss, insanity" (2:111). Nin belongs to a lineage of women whose stories record the imbalanced past and whose pens fight against the falsehoods of identity.

Breaking conventions of her era by choosing to reject monogamy and live a child-free life, Nin was an anomaly. In addition, she defended the right for women to have the freedom of as many relationships as men had been privileged to engage in for centuries. Refusing to act under the sexist culture and literary influences of her time, Nin broke from gender constructs by writing about topics that were previously forbidden to women. Some themes in her work include homoeroticism and the exploration of women's sexuality. Also, metaphors of incest factor heavily in her early writing. As a diarist, engaging a literary genre that blurs the boundaries between truth and fiction, private and public, Nin strove to contend with the head/heart schism of literature. She also wrote fiction that is often difficult to categorize, and is frequently misread as merely self-inflating her own life. More accurately, in her fiction, Nin cobbles together a mythic method, including experimentation with language, and mythic tropes, from a hermeneutics of her own. The mythic tropes in her work testify to tensions that often combine experimental sensuality and physicality on one hand, and a deep desire to transform, create and transcend on another. Moreover, studying Nin's work reminds us that the relationship between the author's life, cultural milieu and work is never straightforward nor should it be. By knowing that life does not explain the entire work, nor does the work explain the life, readers should remain curious and cautious when looking at the myriad ways in which life and art intersect.

Throughout her life Nin was enveloped in a cosmopolitan world of literature, art, music, dance and friendships from all walks of life. In the early 1930s, she published her first book, D. H. Lawrence: An Unprofessional Study, gaining her first public recognition as a writer. At the time, Lawrence's books were banned in the United States and causing scandal throughout Europe. Writing about a literary figure who in many circles was labelled a sexual crusader reveals Nin's pioneering spirit that would infuse her works for the rest of her life. In the late 1930s, Nin began publishing her novellas and short stories. As for the diaries, while they begin in 1914, Volume One (of seven), was not published until 1966. In the later 1960s and 1970s, feminist critics celebrated Nin's lyric prose and fresh subject position. It was a poetic voice about selfhood that many women yearned to hear. However, in the 1980s and 1990s, much of the feminist attention on Nin's literary achievements became exceedingly critical. Her language of feminine embodiment was seen as essentializing the feminine experience. Then the unexpurgated versions of Nin's Diaries, edited and published posthumously in 
the late 1980s and early 1990s, resulted in much sensationalizing by critics, casting a dark shadow on her literary accomplishments. Critics grew fixated with the drama of Nin's life and dismissed her as merely a confessional writer. Even then, some questioned her capacity for truth-telling. By using truth as the main criteria for close reading, some critics at the time accused Nin of fabricating stories, and others dismissed her works as containing merely autobiographical parallels with little to no artistic value.

As I read through some critics' responses to her posthumously published work, I am reminded of how often we hold women to higher, and often double, standards than we do men. We are more forgiving of male writers than of female writers. For Nin, a life of paradoxes often results in shaming and dismissal of her literary opus. I cannot help but wonder, how often is the life of a male writer bonded to events detailing scandal? Henry Miller's literary achievements are not relegated to his years of womanizing. The works F. Scott Fitzgerald wrote during the later years of his life, reflecting on the paradoxes that plagued him, were praised by critics as offering insights into the complexity of the writer at the center of the craft. In contrast, female writers do not seem to occasion the same sympathy and admiration. This context of sexism still animates borders and gender constructs today.

\section{Nin in the 2 Ist century}

The wasteland that prevailed during Nin's time involved a disembodied culture that, while prizing wealth and power, was systemically engineered against women. Nowadays, while women in many parts of the world lead resistance, have more sexual and political freedom, and have the right to choose how they live their lives, sexism, sexist exploitation and oppression within patriarchy still needs to be challenged. The fight to build an equitable society is tied to the struggle of an inability to fully see populations based on gender and race. In some parts of the globe, girls do not control their own bodies, receive no education and struggle to have a voice and their lives be their own. Gender constructs continue to define our identities around the world in various ways.

Throughout the writing of this book, I was unfailingly moved by how deeply relevant still is Nin's ardent quest to realize a voice and to know its polyphonic nature, against androcentric ideologies. In 2016 in the United States there remained a vast uncertainty as to whether a woman had what it took to be president, largely based on her gender. We were told that when women are allowed into politics, they are not permitted to admit to having a separate private and public self. During this same presidential campaign, we were also reminded just how intently sexist politics dominate women's rights. The year I began this book, the largest mass demonstration in American history was organized by women. The Women's March in 2017 was attended by roughly three to five million people in around six hundred cities to advocate for women's rights and to voice intersectional concerns, following the election of Donald Trump as president of the United States. 
While we continue to advocate for an equitable world for all, essential questions of our time are: what images feed our imagination as we desperately need to knit a critical understanding of the harmful structures that surround us? What are the narratives that we tell ourselves in hopes of harmonizing a sense of self, community and who we are in relationship to the earth? Who is willing to engage in this type of self-reflection required to tend to our communities? Nin offers a philosophical justification for why the cultivation of an interior world is essential to address calamities in society: not merely to resist alienation from oneself, but to better bridge our knowledge of others. Nin's feminism brings us a vision that is a necessary truth today: we must foster and affirm life as we oppose domination.

It is my hope that the close reading I offer of Nin's work will encourage a new generation to better recognize not only Nin's willingness to embrace the depths, mystery and fluidity of the creative process, but also to better appreciate the mythic method that she dedicated a lifetime to creating. For we in the 21 st century must continue to find epistemological and aesthetic forms to deepen our understanding of ourselves, which in Gloria Anzaldúa's words ensues as an act of the "freedom to carve and chisel" our own expressions in a culture that must honor a plurality of feminine voices. From her subject position, Nin offers us clues about how to deepen our understanding of archetypal experiences in our own lives, the lives of others, and inspires us to live and write from a mythopoetic stance of one's own.

\section{Works cited}

Anzaldua, Gloria. Borderlands/La Frontera: The New Mestiza. San Francisco: Aunt Lute Books. 1999. Print.

Hinz, Evelyn J. Ed. A Woman Speaks: The Lectures, Seminars, and Interviews of Anaïs Nin. Chicago: Swallow Press. 1975. Print.

Nin, Anaïs. The Diary of Anaïs Nin Volume Two (1934-1939). New York: Harvest. 1969. Print. 
$\because$ Taylor \& Francis

http://taylorandfrancis.com 


\section{Chapter I}

\section{Anaïs Nin}

\section{Self-life writing, myth and literature}

\section{Introduction}

She is the mermaid with her fish-tail dipped in the unconscious. Her creation will be to make articulate this obscure world which dominates man, which he denies being dominated by, but which asserts its domination in destructive proofs of its presence, madness.

(Anais Nin 1937)

Writer and diarist Anaïs Nin (1903-1977), born in Paris to a French-CubanDanish mother and a Cuban father, believed that the intimate connection to one's subjective subtle and intricate developments, if well-tended, could guide the way to the convergence with the rest of humanity. As Nin writes, "the theme of the diary is always the personal, but it does not mean only a personal story. . . . The personal, if it is deep enough, becomes universal, mythical, symbolic" (3:153). Nin echoes not only the then-emerging field of psychology, but also alludes to cherishing the irresolvable voices that speak to the plurality of truths evading a single identity, which her literary works keenly examine. Nin's diaries are a "playground of subjectivities" where self and myth meander, and where death of one aspect of the self births another (Podnieks 66). In this way Nin, the diarist, engages in nature's truest cycle: life, death and rebirth. Nin quotes literary critic Leon Edel in his claim that "the Diary was nothing but a narcissus pool." To which Nin replied, "I have never seen a narcissus pool in which a thousand characters appeared at the same time" (A Woman Speaks 156). By referencing the medium of her diary as a many-voiced theatre where "a thousand characters" perform, Nin's overemphasis is on the creative process of interlocking an ontology of self, including mystery and fantasy, as recorded in both her diary and fiction.

The diary offered Nin the freedom that an artist seeks to discover the polyphony of voices that literature, in turn, explores, as seen in her fiction. In her essay "Speaking in Tongues," Zadie Smith draws our attention to the arduous progression of acquiring the many voices of self in both art and life. In reflecting on the worlds that both language and identity set forth, including the voices we "pick up along the way," Smith reminds us that in literary communities, the artist has been valued for having the flexibility required to speak in various "tongues" (133). To 
illustrate the pivotal point that literature has the capacity to "speak simultaneous truths," she quotes Keats on the gift of Shakespeare's creativity:

At once it struck me, what quality went to form a Man of Achievement especially in Literature and which Shakespeare possessed so enormously . . that is when man is capable of being in uncertainties, Mysteries, doubts, without any irritable reaching, after fact and reason.

(Smith 134)

Nin's diarist and novelist credos value a polyphony of voices often irresolvable and speak to a plurality of truths and experiences, often against a mythic backdrop. These characteristics are suited for more than the psychological and literary potentials of her art. They speak to Nin's perpetual interest in the convergence of art and life as narrative; she began writing in a diary at age 11, and continued until almost the end of her life, at age 73. Nin describes how her initial resolve to write a diary was the synthesis of disparate situations: "it was the way I was going to rebuild the bridge that was broken by the separation of my parents and by the uprooting to a foreign country" ( $A$ Woman Speaks 157). The diary, for Nin, held the "inner journey" that aspiring towards life and art demands. It was a place where "fictionalizing" was "helping the uprooting. To look at it as an adventure was the answer" (A Woman Speaks 223). The "fictionalizing" of a sense of the multiplicity of self is a concept this book thus examines.

This book proposes an analysis of the mythopoesis, the making of myths, by using Nin's diaries, fiction and theory as a conduit, in the works of a female writer. I submit that one should not simply define Nin's work as an attempt to codify an exclusive female aesthetic, or to portray a female artist who successfully integrates her art and her life. Rather, I argue that the continual process of the remaking of a personal myth, the subjective, symbolic and imaginative stories that construct her personal history, may be more fruitful than any single appropriate, authentic achievement.

Early in this book, my analysis explores Nin's work, specifically the prima materia in her diaries, and is initially contextualized within C. G. Jung's notion that the inner experiences pave the path towards becoming conscious of one's psychic process, contributing to self-realization. Jung used the term "personal myth" to suggest that his own personal history of the self-realization of his unconscious was told as a myth, thus indicating a more-than-individual context for meaning. Contextualizing Nin's early works within the conceptual framework of the Jungian paradigm seems to be an organic starting point, for Nin, though younger, was Jung's contemporary and shared some similar views. For example, just as Nin understood that "the personal life, deeply lived, takes you beyond the personal," C. G. Jung assumed that "true art resides in the fact that it has escaped from the limitations of the personal and soared beyond the concerns of the creator" (Jung 71). As a contemporary to Jung, she was also well-engrossed in the 
budding theories on psychic development, including sexuality, trauma and the life of the artist in the 1920s and 1930s. Importantly, Nin's emphasis on gender construction in personal myth may parallel the role of male subjectivity in that of Jung's work. Yet Nin's work does not contain the same authoritative tone or structure of a grand theory in her work. ${ }^{1}$ For it was never Nin's intention, or style, to be objective. Also, one significant distinction between Jung and Nin lies in the scope of time spent probing the inner-self. Nin's diaries span from 1914 to 1974, 60 years. This makes Nin's diaries an important example of the depth and range of self-exploration, perhaps more so than in previous writers. In contrast, Jung's Red Book, while not structured as a diary, records 15 years of his life, from 1915 to $1930 .^{2}$ Moreover, this book does not seek to simply provide a parallel analysis of Nin's and Jung's personal myths; rather, a central question is, what does a close reading of Nin's work reveal about the epistemological and aesthetic methods that comprise a sense of self of a writer?

\section{About this book}

The questions raised in Anaïs Nin: A Myth of Her Own focus on Nin's mythic structure not only as a mode of inquiry, but as poetics of self-construction. Nin includes the personal, the textual, cultural, political and social in a space for the polyphonic sense of self to be created and re-created. In my study, I consider the expurgated editions of Nin's diaries, Volumes One through Seven (1931-1974), and Nin's unexpurgated posthumously published diaries, specifically, The Early Diaries Volume Four (1927-1931) and Incest: From a Journal of Love (1932-1934). Also, by closely reading Nin's novelettes House of Incest, Winter of Artifice and Seduction of the Minotaur, including the critical perspective of a New Historicist, ${ }^{3}$ I trace the ways in which Nin, the weaver of myth, created a mythic method of her own.

In Chapter 2, I situate Nin as a late Modernist writer; from a historical perspective, Modernism characterizes the life and literature of Europe and the Americas in the era roughly between 1914 and 1940. I include a feminist approach to Modernism, which demonstrates that regardless of the claims to impersonality and universality, Modernism as defined by the conventional literary canon encrypts a white, male, heterosexual perspective. This book shows how Nin inevitably worked within male myths and plot structures constructed for the Modernist female artist while creating her own voice and method. By considering the diaries as a "playground of subjectivities" where personal myth is tended and a literary text is shaped, we could better understand how aesthetics of self-construction in an imagined private space, and at times performed, is nonetheless made public through the mediation of language. An analysis of Nin's mythopoetic method should not be equated with a mythologizing of Nin the historical figure. Rather, it is my hope that this mythic paradigm will expand the ontological possibilities from which to value Nin's literary oeuvre, the cultural milieu in which she wrote, and the embodied woman who created them. 
Nin imagined that the female artist has access to two metaphorical worlds at once: the conscious and the unconscious, as "the mermaid with her fish-tail dipped in the unconscious" (2:235-236). Chapter 2 will further analyze the two symbolic worlds Nin references from the perspectives of sky-father and earthmother consciousness, as first proposed by Baring and Cashford in The Myth of the Goddess: Evolution of an Image. Sky-father consciousness values logos, and abstract knowledge. In contrast, earth-mother consciousness values myths and relates to "the moral order of the goddess culture, inherited from the Neolithic." Earth-mother consciousness is "based on the principle of the relationship of the manifest to the unmanifest" (Baring, Cashford 159).

I examine the folktale of Scheherazade from Arabian Nights and the Sumerian myth "Inanna and the God of Wisdom," and show how these characters rely on their cunning and intelligence through the use of trickery and storytelling, as an example of archetypal characteristics that relate to the myth of the diarist. Chapter 3 demonstrates how fitting this mythic perspective is to understanding deeper meaning of the literary diary. My analysis illustrates that the myth of the trickster/ trickstar as an archetypal phenomenon provides a clearer understanding of the polyvocal texture of Nin's diary, as well as the ways in which the diarist includes an inherent earth-mother consciousness to construct a sense of self.

In 1992 Nin's unexpurgated diaries, written in 1933-1934, were posthumously published under the title Incest: From a Journal of Love. Chapter 4 will contextualize these diaries within the emerging theories in the field of psychoanalysis, and Nin's tumultuous relationship with her father. It is within this context that I also analyze Nin's preoccupation with an incest metaphor in House of Incest, written between 1930 and 1933. The 1920s and 1930s were years between wars ravaging Europe, and paralleling critical decades in which Nin worked on crafting a literary style encompassing resultant paradoxes of terror, beauty, love and destruction. Also, as I offer my conjecture as to Nin's motivation for the posthumous publications of her diaries, I consider Nin's own responses to queries involving the editing process of the diaries, as noted in interviews given toward the latter years of her life.

Chapter 5 extends the historical and cultural context established in Chapter 4, by further exploring the intersection of Nin's diarist and novelist credos. Here I investigate Nin's creative process, including the incest metaphor, which is initiated in House of Incest, as it transmogrifies from the posthumously published diaries (1933-1934) into the short story Winter of Artifice. I propose that rather than allowing Nin's posthumously published diaries to be the last word buried in scandal, Incest: From A Journal of Love should be considered within a greater scope of Nin's creative process, and the historical, cultural and literary time period in which they were written, along with intricacies, which I point to, in the final handling of them.

Chapter 6 evaluates Nin's novelette Seduction of the Minotaur as Nin's feminist re-visioning of the ancient minotaur myth. I begin by outlining the literary interests in the minotaur myth prevalent in the backdrop of Nin's own novel. 
By making Ariadne the protagonist, who is associated with the mazes and labyrinths in the myth of the minotaur, Nin captures protagonist Lillian's capacity to embrace her inner landscape as a feminine-embodied and spiritual journey. My analysis shows Nin's ontological understanding of recovering the embodied feminine psyche to suggest that biological bodies do indeed reflect psychic influence.

Anaïs Nin: A Myth of Her Own concludes by considering a recent example of mankind's lost sense of reciprocity with nature, as is evidenced in the developing relationship between the industrialization of food and patenting elements of nature. Here I propose that, as we learn to better live on this planet, diary writing has an eco-minded aspect that may contribute to changing human treatment of non-human nature. I demonstrate that Nin's diaries are a model of exploring the link between language, inner ecologies and self-disclosure, which invites us - often compels us - to take new risks as we reflect on our mythologies. An eco-minded diary can be used as a tool for community building by risking the personal, not merely as an ego-driven effort, but through sensibilities including mythic tropes that link art and life. It is in this way that Nin's work demonstrates a relationship between myth, life and literature that contrasts with other Modernist mythic methods.

\section{Scholarship and the vector of the literary diary}

Anaïs Nin's diaries unveil the process of constructing self, and highlight the relationship between life, myth and narrative. To better understand Nin's contributions to diaries as a literary genre, as well as the theoretical framework I'm proposing through which to understand diaries, including the myth of the diarist, it is first necessary to situate the theoretical definitions of autobiography and to understand when and how diaries enter this debate. This literary and historical context reveals both what autobiographical critics have valued, and how they have defined what constitutes self through the mediation of language. While theoretical definitions of autobiography, constructed by white, male critics, exclude the specific mention of diaries, feminist scholars have challenged those early definitions. I am interested in charting this shift. Prior to the 1970s, women's autobiographical writings were trivialized as a purely confessional mode of writing, not complex enough to warrant literary criticism. The double bind of treating women's self-life writing as merely confessional, and holding them to different standards than self-life writings authored by male writers, particularly in the genres of autobiography and memoir, persisted well in to the 1990s. It is then necessary to first examine general autobiography scholarship, before proceeding to specific scholarship about the diary as a literary and historical context for my own entry into the construction of Nin's mythopoesis.

While women have been writing and contributing to the literary canon for decades, in the 1960s and 1970s, theories of autobiographies continued to dismiss, exclude and misidentify women's self-life writings. An early seminal essay defining autobiographical writing is "A Theory of Autobiography," published in 
1972, by James Olney. According to Olney, autobiography is the place where man sets forth his uniquely creative impulse precisely because autobiography is "an attempt to describe a lifework ... a man's autobiography is thus like a magnifying lens, forcing and intensifying that same peculiar creative vitality that informs all his collected works" (4). Olney argues that the meaning-making process, for each autobiographical writer, is exclusive to his selected metaphors. That is, it is only through metaphors that meaning is constructed. He defines metaphor as "something known and of our making, or at least of our choosing, that we put to stand for, and so to help us understand, something unknown and not of our making" (30). The importance of Olney's contribution to the definition of autobiography is that he posits that metaphor is essentially a way of knowing. By revealing the process in which the psyche realizes itself through metaphor, Olney is also suggesting the link between myth and autobiography, for myth is also a way for the psyche to experience the self metaphorically. Also, the autobiographer, as is true for the diarist, will use the myths central to their being in order to further depict the uniqueness of their subject position.

In a later essay dated 1980, "Autobiography and the Cultural Moment: A Thematic, Historical and Bibliographical Introduction," Olney argues that "the act of autobiography is at once a discovery, a creation, and an imitation of the self" (4). Olney raises questions about identity, creation (as through fiction), and myth in autobiography. He reveals the possibility of broadening the definition of autobiography to include "creation," "discovery" and fiction. Yet in this essay, he excludes the possibility of other forms of autobiography, such as the diary.

In his essay "Conditions and Limits of Autobiography" (published in 1980, originally dated 1956), George Gusdorf posits that the goal of the autobiographer is to reach a conscious understanding of himself. He understands an autobiography as "one of the means to self-knowledge, thanks to the fact that it recomposes and interprets a life in its totality" (38). The notion that an autobiography can hold the totality of a life story does not take into account one of the most fascinating qualities of self-life writing: the ability to which "totality" and "self" might coincide neither in consciousness nor in language. Gusdorf's definition also does not encompass the forms of self-life writing that include the creative unconscious, and those that are not intended to create a cohesive sense of self over time. Gusdorf adds, "each of us tends to think of himself as the center of a living space" (29). The emphasis is thus placed on the "I" as a singularity of importance, for according to Gusdorf, "he is not engaged in an objective and disinterested pursuit but in a work of personal justification" (39). Gusdorf's constricting definition of self-life writing raises issues of self-construction and restricts the motivation of the author's self-importance as a form of mortality. These issues are challenged and re-visioned by feminist scholars such as Domna C. Stanton, Shari Benstock and others. This means that while Gusdorf and Olney limit their focus to the lives of great men such as Augustine, Rousseau and Goethe, whose lives and works assumed their importance as cultural capital, feminist scholars expand the definition to include diaries and other forms of self-life 
writing that include a polyvocal sense of identity, as well as multiple discourses in which women can write.

What emerges from the early theoretical trajectory, as noted above, is evidence that the study of autobiography is justified on the grounds that the genre has a canon that excludes women and men from marginal groups, and a history of valuing the humanist idea of the unique individual moving to locate a unified self. Moreover, in the 1980s, a new body of feminist scholarship was launched in efforts to define women's autobiographies, away from gender essentialist notions. A recurring critical issue for many writers and critics is thus; how to define women's writings without falling into gender essentialism, while still emphasizing that women writers recognize the importance of aesthetic standards, both in their own work and in evaluating that of others.

Importantly, the ensuing decades have brought a shift in the status of autobiography, as feminist scholars of autobiography have re-visioned this definition by looking at the hegemonic discourse - that is, the language of power - that created early autobiography scholarship. To debunk the mainstream definition of autobiography, and to study women's autobiographical practices, feminist scholar Domna C. Stanton proposes the nomenclature "autogynography" to comprise women's autobiography. Stanton edits The Female Autography (1984), and in the opening essay of this collection "Autogynography: Is the Subject Different?" Stanton frames her argument parallel to Virginia Woolf's narrator in A Room of One's Own. Stanton sees women's life writings, existing at the margins of the literary world, as symbolic of an order that places women in a lower status than men. In this way, she examines the interrelations between the problematic of women's place in society and their impulses towards, and modes of, self-life writing. She argues that different from a "phallocentric system," the privileging of rationality deemed as masculine, "the graphing of the auto" was an act of self-assertion that denied and reversed woman's status. To this assertion, Stanton adds that autogynography has a global and "essential therapeutic purpose: to constitute the female subject" (15). Yet despite the aim of self-assertion, the construction of a self is problematized because of women's symbolic status as marginal "other" in patriarchy. Stanton suggests a connection between women's subject position as a "different" standing in the symbolic order, and the notion that the diary is a literary space where the diarist not only explores the conflicting roles within a patriarchal order, and the desire for a creative selfhood, as in Nin's case, but also informs the complex construction of a new mythology to live by. More importantly, by including the word "gyno," as in autogynography, Stanton's nomenclature itself writes the female body into the process of self-life writing, thereby inviting critical observations about the connection between writing and the body.

Stanton contributes the critical point that for women, there has been a deep cultural need to assert a subject position that for too long has been denied and marginalized by androcentric definitions of self-life writing. Her work further emphasizes an attitude of marginalization that the female writer internalizes, and which in many situations fuels the need to construct and assert the female subject 
position, a central theme in Nin's work. A pivotal tension in Nin's literary diaries deals with her effort to define experiences as feminine. Nin was keenly aware and concerned with the tension surrounding what it means to write from a woman's subject position. Yet for her, this concern meant not prescribing an aesthetic for women artists, but learning how to adapt and survive as a female writer. Her diaries provide insight to this creative tension, as I explore in this book.

Moreover, whereas Gusdorf credits the control of the autobiographical writer for its command of its content, Shari Benstock in "The Female Self Engendered: Autobiographical Writing and Theories of Selfhood" sees it as indicative of the overemphasis on authority (1999). Benstock points out that for Gusdorf, the subject is made an object of investigation, and where the gaps exist in the temporal and spatial dimension, so the texts are often successfully hidden from the reader and writer. This makes the narrative seem seamless, organic and overall validating to the understanding that autobiography is a result of the conscious control of artist over subject matter. This relates back to the belief that autobiography is the life history grounded in authority. To advance a critical discussion of autobiography beyond Gusdorf's definition, Benstock poses the critical question of the extent to which the "self" and "self image" might not coincide, or rather, can never coincide in language, as I noted earlier. She emphasizes instead that the process which the autobiographer takes to differentiate himself from others is language: a "symbolic system that both constructs and is constructed by the writing subject" (8). Therefore, one way to describe the notion that the male autobiographer keeps "I" at a greater distance than the female autobiographer, for Benstock, stems from the idea that 'the female autobiographers are more aware of their 'otherness,' but our experience of its social and political effects comes under the terms of another law - that of gender" (8). Here Benstock's argument expounds on the concept that the subject position is an inherently engendered one; this debate has a long historical context that cannot be extricated from our reading of autobiographies, including diaries. It is crucial to recall this gender double bind in diaries and autobiographical writing that has been prevalent for too long. It has been to the immense disadvantage of women throughout history to be considered to have nothing to contribute to greater ways of knowing and being, which is indeed Benstock's point.

Scholars such as Sidonie Smith and Julia Watson, in Women, Autobiography, Theory: A Reader (1998) map the theoretical perspectives on subjectivity that have contributed to the redefinition of autobiography as a literary genre. Smith and Watson take into account the reasons for the growing interest in women's autobiography as well as the shift in perspectives on subjectivity re-formulation. In the 1960s and 1970s, the field of women's autobiographical studies stemmed from a growing academic interest connected to the growth of gender, ethnic and area studies programs interested in fulfilling a demand for texts that speak to diverse experiences from diverse subject positions (5). At the time (1960s and 1970s), women read autobiographies authored by women with a desire to deepen their own understanding of their life. It was the "mirroring" of a women's own 
unvoiced experiences and aspirations that drew most readers to autobiography, and this is the historical time period (1966) of the publications of Volume One of Anaïs Nin's early diaries. It was in the 1970 s that feminist critics sought to recover "the long-out-of-print writings of women over centuries and framing them as a tradition rather than as 'marginal' or 'failed' efforts to write master narratives for male audiences" (Smith and Watson 6).

Importantly, it was through research done by feminist critics on writings of women that later shifted the interest in reading women's autobiographies from merely mirroring a women's experience, to a more analytical exploration of not only the lives of women, but their craft as writers. It is critical to point out that women writers were recognized not only for breaking the silence, but also for their contributions to aesthetic standards. The questioning of gender and race barriers that existed in the literary canon were critical interventions, as they helped rethink literary standards to move away from existing structures of domination. At this point, women could better understand that writing from a subject position of the personal, of having an agenda and political concern was a critical and worthwhile endeavor. As many of the feminist critics point out, the "personal" inspired many women to write, and their dedication to the craft of writing to expand.

\section{Diary scholarship}

The word diary has its roots in the Latin word dies, day, connecting the diary to the ritual of a daily embodied act of writing. Diaries, in the traditional sense, are private accounts of a person's life. Dating from the Heian era in Japan (7941185), diaries were called pillow books, written by women and kept secret. In the West, however, diaries have been considered both personal and public. Contributing to the feminization of the diary was the implementation of the so-called "etiquette books," in the 1800s, "designed to instruct young women how to gauge and improve their feminine conduct through particular diary-keeping habits and techniques" (Podnieks 51). These etiquette books became a "feminized" site for upper- and middle-class women, linking diary writing with privilege, a link reflected in Nin's diary. This historical view traces women's modern experiences with an impulse towards a daily practice of writing a diary. Also, this diaristic history contributes brilliantly to the debate of reasons why works authored by women have been systematically and traditionally marginalized.

Moreover, Robert A. Fothergill in Private Chronicles: A Study of English Diaries (1974), stresses the literary value of the diary as he delivers a historical account of the evolving tradition of the English diary (14). The diary, Fothergill points out, does not have one originating source. Rather, "it is best regarded as the coalescence of a number of pre-diary habits into a form that exceeds its component elements" (14). The pre-diary habits are reflected in four types of diaries such as journals of travel, "public" journals, journals of conscience and journals of personal memorandum (14). 
Consequently, Fothergill reminds us that the specific role that a diarist will accord to his or her diary varies. For many diarists who were also writing in other literary genres, a central function is that the diary serves as a hearth for creative fluidity. Such was the case for many literary women, such as Fanny Burney (1752-1840), Virginia Woolf (1882-1941), and Anaïs Nin (1903-1977). The diaries of these three women in particular break from the tradition of keeping the diary private. In 1788 , at the age of 15 , Burney began writing her diary with an idea that it was to be a place of emotional refuge. She playfully writes, "To have some account of my thoughts, manners, acquaintance and actions, when the hour arrives in which time is more nimble than memory, is the reason which induces me to keep a Journal. A Journal in which I must confess my every thought must open my whole heart!" (18). Burney wrote in her diary until 1840, and it became her major literary work, published in 1832. Beginning in 1915, Virginia Woolf kept a diary, and at the age of 22 , she began to use the diary as a way to seriously explore its capacity as a literary form for its flexibility. In a diary entry dated October 23, 1917, Woolf reflects: "another lapse in this book, I must confess; but, if I do it against my humour I shall begin to loathe it; so the one chance of life it has is to submit to lapses uncomplainingly" (1:65). Woolf finds comfort in the diary's capacity to contain fluidity and spontaneity. Also, she comes to experience her diary as a place for liberation and ease. In a later entry of 1939, Woolf notes: "oh how gladly I reach for this free page for a 10 minute scamper after copying and re-copying, digging in these old extract books for quotes all the morning?" $(3: 244)$. Anaïs Nin, too at times, regards the diary as a means to envelop herself in freedom of expression and comfort: "I do not feel this tension when I am writing. I am at ease in the diary. When will creation and life fuse for me, and when will I be equally at ease in both?" (5:39). Later in her life, the purpose of her diary morphed into a life-holding vessel: "Life only became real when I wrote about it" (7:310). It was the flexibility of the genre that Nin praises: "At twenty it's different from thirty and at thirty it's different from at forty ... this year it has become a correspondence with the world, and probably that is the right ending for a diary, that it would start as a river and then flow into an ocean" (A Woman Speaks 180). In its mercurial flexibility, the literary diary is a place to "get lost" and re-claim psychological and poetic insight.

From a mythic perspective, being called to the diary day after day evokes an image of Hestia, the first Olympian who is placed in the center of Greek life as the hearth. Through her glowing, warm coals, Hestia grounds the diarist in both a physical and psychological space to write oneself a home. In the Homeric hymn, Hestia protects and bestows humankind with good things. Hestia's myth is a reminder for the diarist as $\mathrm{s} / \mathrm{he}$ collects a composite of myths seeking form and coherence, to not only entertain and warm up to ideas, but to value a psychic homecoming that inspires a place for creativity. James Hillman, in his essay "In: Hestia's Preposition," sees Hestia as one who "governs the inner psychic structure" (238). As the goddess of slow-burning yet smoldering coals, akin to contemplation, Hestia holds the power to bring the soul into a state of dwelling inside a 
hearth. The spatial metaphor that holds creativity evokes a sanctified space for the diarist to reside.

In her essay "Mimesis: The Dramatic Lineage of Auto/Biography" (1987), Evelyn J. Hinz emphasizes three dramatic characteristics in autobiography and the diary, such as elements of conflict and dialogue, a sense of performance and/ or spectatorship and a mimetic or referential quality. Hinz links drama into the ancestry of self-life writing. By acknowledging these dramatic affinities, according to Hinz, we come to see drama as the "sister art" for autobiographies and diaries (209). Hinz, moreover, parallels the life of the actor as taking on another self with that of the autobiographer (200). Interestingly, she connects Nin as the "most famous twentieth-century diarist" with an aspiring stage performer. This is a topic that I delve into further in Chapter 3.

The link between diaries and the recurrent "patterns of experience" relate to the archetypal qualities, images from the unconscious that animate the individual and the collective, in the myth of the diarist that this book examines. Hinz values the dramatizing quality in self-life writing, as does Nin in her diaries. The affinities between self-life writing and drama, resonate with a depth psychological understanding of ritual, writing and performance. James Hillman writes, "the ritual of theater, of religion, of loving, and of play require concrete actions which are never only what they literally seem to be" (137). He reminds us that ritual motions have a way of psychologizing and of deliteralizing events as they are performed. A critical question I investigate is, what does a close reading of the archetypes in Nin's diaries from the hermeneutics of depth psychology reveal about myth, fantasy, performance and self-construction? I look at this specifically in Chapter 3.

Judy Simons's book Diaries and Journals of Literary Women from Fanny Burney to Virginia Woolf (1990), informs my work on Nin's diaries as a genre that allows women a subversive space for self-creation. Simons argues that despite the restricted forms of expression, women have, through their diaries, been able to break hegemonic conventions and provide decisive and coherent images of self (196). Her study of diarists includes Dorothy Wordsworth, Mary Shelley, Elizabeth Barrett Browning, Louisa May Alcott, Edith Wharton, Katherine Mansfield and Virginia Woolf. Simons's study poses such questions as, what relationship can be traced between personal writings and literary texts for publication by the same author? Do the diaries offer insight into the unique difficulties women might have faced in the production of literature? I will consider these questions specific to Nin's diaries and fiction later in this book.

An examination of the ongoing critical conversation regarding diary discourse and the academy can be found in Gender and the Journal: Diaries and Academic Discourse (1992), by Cinthia Gannett. The early part of her study looks at the various motivations for a diarist to write and how such motivations could relate to gender. Gannett argues that the difference in gender discourse "lies in that a woman's relationship to language remains paradoxical, as the word is simultaneously foreign and familiar" (47). Thus, in order to speak or write, women "must both/either accommodate to this alienation, and/or find alternative modes of expressions - ways 


\section{Anaïs Nin}

Baring, Anne and Jules Cashford. The Myth of the Goddess: Evolution of an Image. New York: Penguin Books. 1991. Print.

Benstock, Shari. "The Female Self Engendered: Autobiographical Writing and Theories of Selfhood." Women and Autobiography. Eds. Martine Watson Brownley and Allison B. Kimmich . Wilmington: Scholarly Resources Inc. 1999. Print.

Bloom, Lynn Z. "I Write for Myself and Strangers": Private Diaries as Public Documents." Inscribing the Daily: Critical Essays on Women's Diaries. Eds. Suzanne L. Bunkers and Cynthia A. Huff . Amherst: $U$ of Massachusetts P. 1996. Print.

Burney, Fanny. The Early Diary of Frances Burney, (1768-1778). Ed. Annie Raine Ellis . London: Dent. 1907. Print.

Fothergill, Robert A. Private Chronicles: A Study of English Diaries. London: Oxford UP. 1974. Print.

Gannett, Cinthia. Gender and the Journal: Diaries and Academic Discourse. Albany: State U of New York P. 1992. Print.

Gusdorf, Georges. "Conditions and Limits of Autobiography." Autobiography: Essays

Theoretical and Critical. Ed. James Olney . Princeton: Princeton UP. 1980. Print.

Hillman, James. Re-visioning Psychology. New York: Harper \& Row. 1975. Print.

Hillman, James. "In: Hestia's Preposition." Mythic Figures. Putnam: Spring Publications. 2007.

Print.

Hinz, Evelyn J. Ed. A Woman Speaks: The Lectures, Seminars, and Interviews of Anaïs Nin. Chicago: Swallow Press. 1975. Print.

Hinz, Evelyn J. "Mimesis: The Dramatic Lineage of Auto/Biography." Essays on Life Writing:

From Genre to Critical Practice. Toronto: Toronto UP. 1992. Print.

Jackson, Anna. Diary Poetics: Form and Style in Writers' Diaries, 1915-1962. New York:

Routledge. 2010. Print.

Jung, C. G. Memories, Dreams, Reflections. New York: Random House. 1989. Print.

Kadar, Marlene. "Coming to Terms: Life Writing - from Genre to Critical Practice." Essays on Life Writing: From Genre to Critical Practice. Toronto: Toronto UP. 1992. Print.

Nin, Anaïs. The Diary of Anaïs Nin Volume Three (1939-1944). New York: Harvest. 1969a.

Print.

Nin, Anaïs. The Diary of Anais Nin Volume Two (1934-1939). New York: Harvest. 1969b. Print. Nin, Anaïs. The Diary of Anaïs Nin Volume Five (1947-1955). New York: Harvest. 1969c. Print. Nin, Anaïs. The Diary of Anaïs Nin Volume Seven (1966-1974). New York: Harvest. 1969d. Print.

Olney, James. "Autobiography and the Cultural Moment: A Thematic, Historical and

Bibliographical Introduction." Autobiography: Essays Theoretical and Critical. Ed. James Olney . Princeton: Princeton UP, 1980. Print.

Nin, Anaïs. "A Theory of Autobiography." Autobiography: Essays Theoretical and Critical. Princeton: Princeton UP. 1980.

Podnieks, Elizabeth. Daily Modernism: The Literary Diaries of Virginia Woolf, Antonia White, Elizabeth Smart, and Anaïs Nin. London: McGill-Queen's UP. 2000. Print.

Simons, Judy. Diaries and Journals of Literary Women from Fanny Burney to Virginia Woolf. lowa City: lowa UP. 2001. Print.

Smith, Sidonie and Julia Watson , Ed. Women, Autobiography, Theory: A Reader. London:

Wisconsin UP. 1998. Print.

Smith, Zadie. Changing My Mind: Occasional Essays. New York: Penguin Books. 2009. Print.

Stanton, Domna C. The Female Autography. New York: C.U.N.Y. 1984. Print.

Woolf, Virginia. The Diary of Virginia Woolf, Volume 1 (1915-1919). Ed. Anne Olivier Bell . New York: Harvest. 1977. Print.

Woolf, Virginia. The Diary of Virginia Woolf, Volume 3 (1925-1930). Ed. Anne Olivier Bell . New York: Harvest. 1980. Print. 


\section{Anaïs Nin's expurgated diaries Volume One (1931-1934) and Two (1934-1939)}

Baring, Anne and Jules Cashford. The Myth of the Goddess: Evolution of an Image. New York: Penguin Books. 1991. Print.

Benstock, Shari. Women of the Left Bank: Paris, 1900-1940. Texas: Texas UP. 1986. Print. Benstock, Shari. Women's Writing in Exile. Chapel Hill: The U of North Carolina P. 1989. Print. Coupe, Laurence. Myth. London: Routledge. 1997. Print.

Eliot, T. S. "Ulysses, Order and Myth." Selected Prose of T.S. Eliot. New York: Harcourt Brace Jovanovich. 1956. Print.

Harms, Valerie. "Anaïs and Her Analyst, Rank and Allendy: The Creative and Destructive Aspects." Literary Perspectives. Ed. Suzanne Nalbantian . New York: St. Martin's Press. 1997. Print.

Hinz, Evelyn J. Ed. A Woman Speaks: The Lectures, Seminars, and Interviews of Anaïs Nin. Chicago: Swallow Press. 1975. Print.

Jung, C. G. "On the Relation of Analytical Psychology to Poetry." Modern Man in Search of a Soul. New York: Harvest. 1933. Print.

Jung, C. G. Memories, Dreams, Reflections. New York: Random House. 1989. Print.

Knapp, Bettina L. Anaïs Nin. New York: Frederick Ungar Publishing. 1978. Print.

Knapp, Bettina L. Recollections of Anaïs Nin by Her Contemporaries. Ed. Benjamin Franklin V. Athens: Ohio UP. 1996. Print.

Lee, Hermione. Virginia Woolf. New York: Alfred A. Knopf. 1997. Print.

McGann, Jerome J. "'The Grand Heretics of Modern Fiction': Laura Riding, John Cowper Powys, and the Subjective Correlative." Modernism/Modernity 13.2 (2006): 309-323. Project MUSE. Web. 13 August 2014.

Nin, Anaïs. The Novel of the Future. New York: Collier Books. 1968. Print.

Nin, Anaïs. The Diary of Anaïs Nin Volume One (1931-1934). New York: Harvest. 1969a. Print. Nin, Anaïs. The Diary of Anaïs Nin Volume Two (1934-1939). New York: Harvest. 1969b. Print. Nin, Anaïs. Linotte: The Early Diary of Anaïs Nin (1914-1920). New York: Harcourt Brace Jovanovich. 1978. Print.

Nin, Anaïs. Incest: From A Journal of Love (1932-1934). New York: Harcourt Brace Jovanovich. 1992. Print.

Parker, Arthur C. Seneca Myths and Folk Tales. Lincoln: Nebraska UP. 1923. Print.

Podnieks, Elizabeth. Daily Modernism: The Literary Diaries of Virginia Woolf, Antonia White, Elizabeth Smart, and Anaïs Nin. London: McGill-Queen's UP. 2000. Print.

Scott, Bonnie Kime. The Gender of Modernism. Bloomington: Indiana UP. 1990. Print.

Scott, Bonnie Kime . Refiguring Modernism. Vol. 1. Bloomington: Indiana UP. 1995. Print.

Spencer, Sharon. "Beyond Therapy: The Enduring Love of Anaïs Nin for Otto Rank." Anaïs Nin: Literary Perspectives. Ed. Suzanne Nalbantian . New York: St. Martin's Press. 1997. Print. Tookey, Helen. Anais Nin, Fictionality and Feminity: Playing a Thousand Roles. Oxford: Oxford UP. 2003. Print.

Woolf, Virginia. Mrs. Dalloway. New York: Harcourt Brace Jovanovich. 1925. Print.

Woolf, Virginia. "Women Novelists." Essays on Twentieth-Century Books and Authors by Virginia Woolf. New York: Harvest. 1965. Print.

Woolf, Virginia. "Modern Fiction." The Essays of Virginia Woolf. Vol. 4. 1925-1928. London: The Hogarth Press. 1984. Print.

Zinnes, Harriet. "Art, the Dream, the Self." Anaïs Nin: Literary Perspectives. Ed. Suzanne Nalbantian . New York: St. Martin's Press. 1997. Print. 


\section{Risks and tricks in the myth of the diarist}

Cooper, Paul Fenimore. The Tricks of Women and Other Albanian Tales. New York: William Morrow and Company. 1927. Print.

Dickinson, Emily. "Tell All the Truth But Tell It Slant (1129)." The Poems of Emily Dickinson. Ed.

Ralph W. Franklin . Cambridge: The Belknap Press of Harvard UP. 1951. Print.

Estes-Pinkola, Clarissa . Women Who Run With the Wolves: Myths and Stories of the Wild Woman Archetype. New York: Ballantine Books. 1992. Print.

Henke, Suzette. Recollections of Anaïs Nin by Her Contemporaries. Ed. Benjamin Franklin V. Athens: Ohio UP. 1996. Print.

Hillman, James. Re-visioning Psychology. New York: Harper \& Row. 1975. Print.

Hinz, Evelyn J. Ed. A Woman Speaks: The Lectures, Seminars, and Interviews of Anaïs Nin.

Chicago: Swallow Press. 1975. Print.

Hyde, Lewis. Trickster Makes This World: Mischief, Myth, and Art. New York: North Point Press. 1998. Print.

Hynes, William J. "Inconclusive Conclusion: Tricksters - Metaplayers and Revealers." Mythical Trickster Figures: Contours, Contexts, and Criticism. Eds. William J. Hynes, William G. Doty . Alabama: Tuscaloosa UP. 1993. Print.

Jung, C. G. (1969). Memories, Dreams, Reflections. New York: Random House. 1989. Print. Jurich, Marilyn. Scheherazade's Sisters: Trickster Heroines and Their Stories in World Literature. Westport: Greenwood Press. 1998. Print.

Kadar, Marlene. "Coming to Terms: Life Writing - from Genre to Critical Practice." Essays on Life Writing: From Genre to Critical Practice. Toronto: Toronto UP. 1992. Print.

Knapp, Bettina L. Anais Nin. New York: Frederick Ungar Publishing. 1978. Print.

Nalbantian, Suzanne. "Aesthetic Lies.” Anaïs Nin: Literary Perspectives. New York: St. Martin's Press. 1997. Print.

Nin, Anaïs. D. H. Lawrence: An Unprofessional Study. Chicago: Swallow Press. 1964. Print. Nin, Anaïs. The Diary of Anaïs Nin Volume One (1931-1934). New York: Harvest. 1969a. Print. Nin, Anaïs. The Diary of Anaïs Nin Volume Two (1934-1939). New York: Harvest. 1969b. Print. Nin, Anaïs. The Diary of Anaïs Nin Volume Five (1947-1955). New York: Harvest. 1969c. Print. Nin, Anaïs. The Diary of Anaïs Nin Volume Six (1955-1966). New York: Harvest. 1969d. Print. Nin, Anaïs. The Diary of Anaïs Nin Volume Seven (1966-1974). New York: Harvest. 1969e. Print.

Nin, Anaïs. Linotte: The Early Diary of Anaïs Nin (1914-1920). New York: Harcourt Brace Jovanovich. 1978. Print.

Nin, Anaïs. Incest: From A Journal of Love (1932-1934). New York: Harcourt Brace Jovanovich. 1992. Print.

Paris, Ginette. Pagan Meditations: Aphrodite, Hestia, Artemis. Dallas: Spring Publications. 1986. Print.

Podnieks, Elizabeth. Daily Modernism: The Literary Diaries of Virginia Woolf, Antonia White, Elizabeth Smart, and Anaïs Nin. London: McGill-Queen's UP. 2000. Print.

Richard-Allerdyce, Diane. Anaïs Nin and the Remaking of Self: Gender, Modernism, and Narrative Identity. Dekalb: Northern Illinois UP. 1998. Print.

Rowland, Susan. The Ecocritical Psyche: Literature, Evolutionary Complexity and Jung. New York: Routledge. 2012. Print.

Snyder, Robert. Anaïs Nin Observed: From a Film Portrait of a Woman Artist. Chicago: Swallow Press. 1976. Print.

Tookey, Helen. Anaïs Nin, Fictionality and Femininity: Playing a Thousand Roles. Oxford: Oxford UP. 2003. Print.

Wessels, Leana. "An Analysis of the Extent to Which the Trickster Archetype Can Be Applied to the Goddess Inanna/Ishtar." Journal for Semitics 22.1 (2013): 35-33. Project MUSE. Web. 11 November 2014.

Wolkstein, Diane and Samuel Noah Kramer . Inanna: Queen of Heaven and Earth: Her Stories and Hymns from Sumer. New York: Harper \& Row. 1983. Print. 


\section{(Un)veiling incest}

Benstock, Shari. Women of the Left Bank: Paris, 1900-1940. Texas: Texas UP. 1986. Print. Benstock, Shari. Women Writers in Exile. Chapel Hill: The U of North Carolina P. 1989. Print. Blume, Lesley M. Everybody Behaves Badly: The True Story Behind Hemingway's Masterpiece The Sun Also Rises. New York: Houghton Mifflin Harcourt Publishing. 2016. Print.

Hinz, Evelyn J. Ed. A Woman Speaks: The Lectures, Seminars, and Interviews of Anaïs Nin. Chicago: Swallow Press. 1975. Print.

Jung, C. G. "Analytical Psychology and Education." The Development of Personality, The Collected Works of C. G. Jung. CW Vol. 17, pp. 63-132. Eds. Sir Herbert Reed, Dr. Michael Fordham and Dr. Gerhard Adler, translated by R. F. C. Hull . London: Routledge; Princeton: Princeton UP. (1946-54).

Jung, C. G. "Psychic Conflicts in a Child." The Development of Personality. The Collected Works of C. G. Jung. CW Vol. 17, pp. 1-135. Eds. Sir Herbert Reed, Dr. Michael Fordham and Dr. Gerhard Adler, translated by R. F. C. Hull . London: Routledge; Princeton: Princeton UP. (1946-54).

Jung, C. G. "On Psychology of the Unconsciousness." Two Essays in Analytical Psychology. The Collected Works of C. G. Jung. CW Vol. 7, pp. 1-119. Eds. Sir Herbert Reed, Dr. Michael Fordham and Dr. Gerhard Adler, translated by R. F. C. Hull . London: Routledge; Princeton: Princeton UP. (1943-66).

Jung, C. G. Memories, Dreams, Reflections. New York: Random House. 1989. Print. Loy, Mina. "Feminist Manifesto." The Lost Lunar Baedeker: Poems of Mina Loy. Ed. Roger L. Conover . New York: Farrar, Straus and Giroux. 1996. Print.

Nin, Anaïs. House of Incest. Chicago: Swallow Press. 1958. Print.

Nin, Anaïs. D. H. Lawrence: An Unprofessional Study. Chicago: Swallow Press. 1964. Print. Nin, Anaïs. The Diary of Anaïs Nin Volume One (1931-1934). New York: Harvest. 1969a. Print. Nin, Anaïs. The Diary of Anaïs Nin Volume Three (1939-1944). New York: Harvest. 1969b. Print.

Nin, Anaïs. Waste of Timelessness and Other Early Short Stories. Chicago: Swallow Press. 1977. Print.

Nin, Anaïs. The Early Diary of Anaïs Nin, Volume Four (1927-1931). New York: Harcourt Brace Jovanovich. 1985. Print.

Nin, Anaïs. Henry and June. New York: Harvest. 1986.

Nin, Anaïs. Incest: From A Journal of Love (1932-1934). New York: Harcourt Brace Jovanovich. 1992. Print.

Nin, Anaïs. Winter of Artifice. Chicago: Swallow Press. 1945. Print.

Podnieks, Elizabeth. Daily Modernism: The Literary Diaries of Virginia Woolf, Antonia White, Elizabeth Smart, and Anaïs Nin. London: McGill-Queen's UP. 2000. Print.

Rank, Otto. Art and Artist: Creative Urge and Personality Development. New York: W.W. Norton. 1932. Print.

Rowland, Susan. The Ecocritical Psyche: Literature, Evolutionary Complexity and Jung. New York: Routledge. 2012. Print.

Rudnytsky, Peter. "Introduction." The Incest Theme in Literature and Legend. Ed. Otto Rank . Baltimore: John Hopkins UP. 1991. Print.

Spencer, Sharon. "Beyond Therapy: The Enduring Love of Anaïs Nin for Otto Rank." Anaïs Nin: Literary Perspectives. Ed. Suzanne Nalbantian . New York: St. Martin's Press. 1997. Print. 


\section{The literary credo of a diarist and novelist as traced in Incest: From A Journal of Love and Winter of Artifice}

Didion, Joan. The White Album. New York: Simon and Schuster. 1979. Print.

Hinz, Evelyn J. Ed. A Woman Speaks: The Lectures, Seminars, and Interviews of Anaïs Nin.

Chicago: Swallow Press. 1975. Print.

Nalbantian, Suzanne. Aesthetic Autobiography: From Life to Art in Marcel Proust, James Joyce, Virginia Woolf and Anaïs Nin. New York: St. Martin's Press. 1994. Print.

Nin, Anaïs. Winter of Artifice. Chicago: Swallow Press. 1945. Print.

Nin, Anaïs. Seduction of the Minotaur. Athens: Ohio UP. 1961. Print.

Nin, Anaïs. D. H. Lawrence: An Unprofessional Study. Chicago: Swallow Press. 1964. Print.

Nin, Anaiis. The Novel of the Future. New York: Collier Books. 1968. Print.

Nin, Anaïs. The Diary of Anaïs Nin Volume One (1931-1934). New York: Harvest. 1969a. Print.

Nin, Anaïs. The Diary of Anaïs Nin Volume Four (1944-1947). New York: Harvest. 1969b. Print.

Nin, Anaïs. Incest: From a Journal of Love (1932-1934). New York: Harcourt Brace Jovanovich. 1992. Print.

Rank, Otto. Art and Artist: Creative Urge and Personality Development. New York: W.W.

Norton. 1932. Print.

\section{Myth, monsters and art}

Baring, Anne and Jules Cashford. The Myth of the Goddess: Evolution of an Image. New York: Penguin Books. 1991. Print.

Borges, Jorge Luis . "The House of Asterion." Labyrinths: Selected Stories and Other Writings. New York: New Directions. 1964. Print.

Borges, Jorge Luis "Parable of Cervantes and the Quixote." Collected Fictions: Volume 3. New York: Penguin, Random House. 1998. Print.

Coupe, Laurence. Myth. London: Routledge. 1997. Print.

Knapp, Bettina L. Anaïs Nin. New York: Frederick Ungar Publishing. 1978. Print.

Nalbantian, Suzanne. Memory in Literature: From Rousseau to Neuroscience. Basingstoke:

Palgrave Macmillan. 2003. Print.

Nin, Anaïs. Seduction of the Minotaur. Athens: Ohio UP. 1961. Print.

Nin, Anaïs. The Novel of the Future. New York: Collier Books. 1968. Print.

Nin, Anaïs. The Diary of Anaïs Nin Volume Five (1947-1955). New York: Harvest. 1969. Print.

Paris, Ginette. Pagan Meditations: Aphrodite, Hestia, Artemis. Dallas: Spring Publications.

1986. Print.

Paris, Ginette. Pagan Grace: Dionysos, Hermes, and Goddess Memory in Daily Life. Putnam: Spring Publications. 1990. Print.

Rowland, Susan. The Ecocritical Psyche: Literature, Evolutionary Complexity and Jung. New York: Routledge. 2012. Print.

Warner, Marina. "Boys Will be Boys." Six Myths of Our Time. New York: Vintage. 1994. Print. Ziolkowski, Theodore. Minos and the Moderns: Cretan Myth in Twentieth Century Literature and Art. New York. Oxford UP. 2008. Print.

\section{Epilogue}

Glotfelty, Cheryll. "Introduction: Literary Studies in an Age of Environmental Crisis." The

Ecocriticsm Reader. Eds. Cheryll Glotfelty and Harold Fromm . London: The U of Georgia P. 1996. Print.

Hinz, Evelyn J. Ed. A Woman Speaks: The Lectures, Seminars, and Interviews of Anaïs Nin.

Chicago: Swallow Press. 1975. Print.

Holy Bible: The New King James Version. New York: ABS. 1982. Print. 
Nin, Anaïs. The Novel of the Future. New York: Collier Books. 1968. Print.

Nin, Anaïs. The Diary of Anaïs Nin Volume One (1931-1934). New York: Harvest. 1969a. Print. Nin, Anaïs. The Diary of Anaïs Nin Volume Six (1955-1966). New York: Harvest. 1969c. Print. Nin, Anaïs. The Diary of Anaïs Nin Volume Seven (1966-1974). New York: Harvest. 1969d. Print.

Parker, Arthur C. Seneca Myths and Folk Tales. Lincoln: Nebraska UP. 1923. Print.

Pereira, Sidney. "What Is 'True Environmentalism'? Here's What Trump's EPA Had to Say." December 29, 2017. Newsweek. www.newsweek.com/epa-admin-scott-pruitt-thinks-usingfossil-fuels-true-environmentalism-760265.

Robin, Marie-Monique . The World According to Monsanto: Pollution, Corruption, and the Control of Our Food Supply. New York: New Press. 2008. Print.

Rowland, Susan. The Ecocritical Psyche: Literature, Evolutionary Complexity and Jung. New York: Routledge. 2012. Print.

Rueckert, William. "Literature and Ecology: An Experiment in Ecocriticsm." The Ecocriticsm Reader. Eds. Cheryll Glotfelty and Harold Fromm . London: Georgia UP. 1996. Print. Shiva, Vandana. Soil Not Oil. New York: South End Press. 2008. Print. Zapf, Hubert. Literature as Culture Ecology. London: Bloomsbury Academic. 2016. Print. 